\title{
Laboratory Evaluation of the Effectiveness of Pathogen Reduction Procedures for Bacteria
}

\author{
Thomas H. Müller ${ }^{a} \quad$ Thomas Montag $^{b} \quad$ Axel W. Seltsam ${ }^{a}$ \\ ${ }^{\text {a }}$ DRK-Blutspendedienst NSTOB, Institut Springe, \\ ${ }^{b}$ Paul-Ehrlich Institute, Langen, Germany
}

\section{Keywords}

Bacteria, pathogen reduction - Platelet concentrate . Cellular blood component . Sterility

\section{Summary}

Bacterial contamination remains a leading factor for transfusion-associated serious morbidity and mortality. Pathogen reduction procedures offer a pro-active approach to prevent bacterial contamination of cellular blood components and especially of platelet concentrates. In the past, the laboratory evaluation of the effectiveness of the pathogen reduction procedures to minimise the bacterial load of blood components has been primarily based on log reduction assays similar to the assessment of antiviral activities. Bacteria strains with the ability to multiply in the blood components are seeded in highest possible cell numbers, the pathogen reduction procedure is applied, and the post-treatment number of bacteria is measured. The effectiveness of the procedure is characterised by calculating the log reduction of the post- to pre-treatment bacteria titres. More recently, protocols have been developed for experiments starting with a low bacteria load and monitoring the sterility of the blood component during the entire storage period of the blood component. Results for 3 different pathogen reduction technologies in these experimental models are compared and critical determinants for the results are addressed. The heterogeneity of results observed for different strains suggests that the introduction of international transfusion-relevant bacterial reference strains may facilitate the validity of findings in pathogen reduction experiments.

\author{
Schlüsselwörter \\ Bakterien - Pathogenreduktion . \\ Thrombozytenkonzentrate - Zelluläre Blutkomponenten . \\ Sterilität
}

\section{Zusammenfassung}

Bakterielle Kontaminationen gehören nach wie vor zu den führenden Ursachen für transfusionsassoziierte schwerwiegende Krankheits- und Todesfälle. Verfahren zur Pathogenreduktion eröffnen eine proaktive Strategie, um das Risiko bakterieller Kontaminationen bei zellulären Blutkomponenten und insbesondere bei Thrombozytenkonzentraten zu minimieren. In der Vergangenheit standen bei der Laboruntersuchung der Wirksamkeit von Pathogenreduktionsverfahren für Bakterien, ähnlich wie für Viren, Log-Reduktionsexperimente im Vordergrund. Dazu werden die Präparate mit Bakteriensuspensionen in höchst möglicher Zellzahl beimpft. Unmittelbar nach Abschluss des Pathogenreduktionsverfahrens wird der Restgehalt an proliferationsfähigen Bakterien ermittelt. Die Log-Reduktion der Bakterientiter wird als Maß für die Wirksamkeit des Verfahrens berechnet. Mittlerweile wird dies Vorgehen durch Untersuchungen zur Sterilität während der Präparatelaufzeit ergänzt. Dazu werden Blutkomponenten mit relativ niedriger Bakterienlast beimpft und anschließend mit dem Pathogenreduktionsverfahren behandelt. Ergebnisse für drei unterschiedliche Pathogenreduktionsverfahren in diesen beiden Modellen werden verglichen und kritische Einflussfaktoren angesprochen. Sie lassen erwarten, dass mit der Verfügbarkeit von Bakterienstämmen als international etabliertem transfusions-relevantem Referenzmaterial die Aussagekraft von Untersuchungen zur Pathogenreduktion für Bakterien wesentlich verbessert werden kann.

\begin{tabular}{ll}
\hline KARGER & @ 2011 S. Karger GmbH, Freiburg \\
Fax +497614520714 & Accessible online at: \\
Information@Karger.de & www.karger.com/tmh \\
www.karger.com &
\end{tabular}

Prof. Dr. Thomas H. Mülle

DRK- Blutspendedienst NSTOB

Eldagsener Str. 38, 31832 Springe, Germany

mueller@bsd-nstob.de 
Platelet concentrates contaminated with bacteria can transmit the pathogens to the recipients. Diverse measures, including optimisation of skin disinfection methods [1-6], introduction of pre-donation sampling [6-8] and screening methods [7, 9-17], have been implemented with tremendous efforts and resources in the past years to reduce the risk of bacterial infection and sepsis. Nevertheless, the risk of bacterial infections due to platelet transfusions and red blood cell transfusions remains an important or even the leading cause of severe morbidity and mortality in transfusion medicine [18-20]. Fresh-frozen plasma, handled in the appropriate ways and despite reports of a substantial rate of positive findings in sterility testing [21], however, appears not to be a relevant vehicle for bacteria transmission [22] as bacteria are not able to proliferate during deep-frozen storage.

Pathogen reduction technologies introduce an universal approach [23-26] to substantially reduce the residual risk of bacterial contamination. The different procedures for pathogen reduction of blood components have been summarised in detail [27-33]. The purpose of this review is to address pivotal issues in the assessment of the effectiveness of pathogen inactivation procedures for the reduction of bacterial contaminations.

\section{Specific Threats of Bacteria as Contaminations of Blood Components}

A fundamental difference between viruses and bacteria as contaminants of blood components is the ability of bacteria to multiply during the preparation and storage of the blood component.

In principle, three different settings characterise the growth behaviour of bacteria in blood components as outlined in figure 1 by displaying the bacterial load on a logarithmic scale as a function of the duration of storage.

It is very likely that low numbers of bacteria may initially be present in most blood-derived preparations. Non-specific host defence mechanisms including complement activation in the presence of plasma or phagocytosis by leucocytes after opsonisation have the power to eliminate or inactivate the bacteria and thus 'sterilise' the blood component. The latter effect depends on the contaminating bacterial strain, i.e. only those strains can be eliminated by mechanisms of innate immunity which are not armed by certain virulence markers (e.g. phagocytosis resistance and resistance towards complement killing). It is tempting to speculate that in addition specific immune mechanisms, as for example circulating antibodies from previous exposure to bacteria, are able to enhance this process of 'self-sterilisation' of the blood component even in case of pathogenic bacteria. If care is taken to avoid any contamination during the further processing and handling of the component on its way to the recipient, the product will be free of bacteria and any risk of transfusion-transmitted bacterial infection. Qualitative and quantitative studies of the mecha-

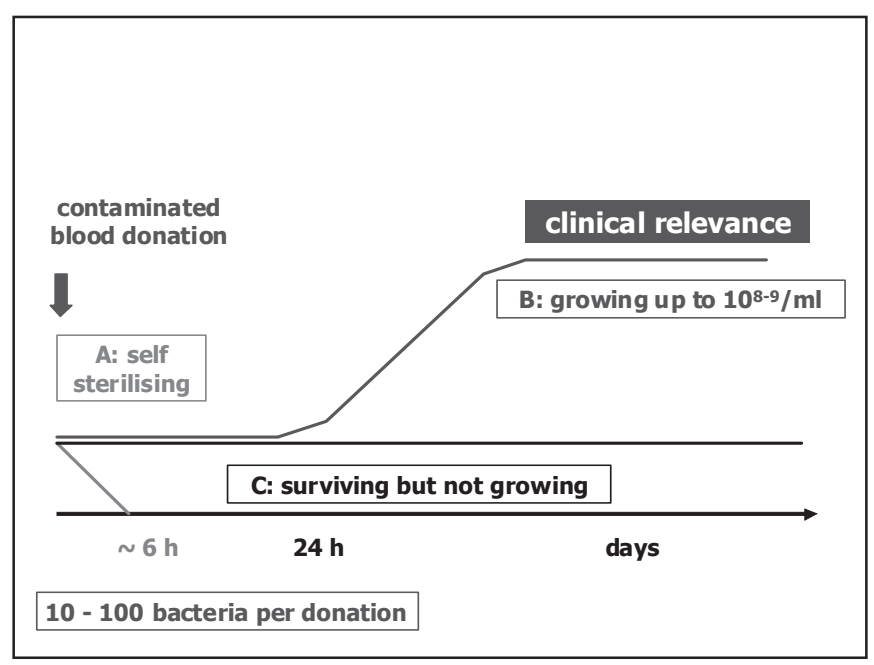

Fig. 1. Growth behaviour of different bacterial strains after contamination of a blood donation.

nisms ensuring this most common scenario are missing. Therefore it is difficult to identify the critical determinants for this scenario (growth pattern A in fig. 1.).

The other extreme is represented by continuous growth of the bacteria present in the component (growth pattern B in fig. 1). Adequate conditions for the continuous propagation of micro-organisms with a relatively short duplication rate $(<1 \mathrm{~h}$ to few hours) can easily result in exponential growth of the bacteria. In this scenario of rapid growth, a relatively low initial load of bacteria ( $<20$ bacteria/component [34]) suffices to accumulate substantial numbers of bacteria in the product during storage which is associated with life-threatening complications for the transfusion. This scenario does explain the limitation of bacterial screening of blood components by early sampling, i.e. $24 \mathrm{~h}$ or less post-preparation [14, 34]. A low initial load of bacteria may easily escape the detection ('sampling error'). It does, however, not exclude that the few bacteria can grow to meaningful numbers. False-negative results for early sampling procedures implemented for bacterial screening of platelet concentrates have reproducibly been reported.

A third scenario has been occasionally observed: the contaminating bacteria are not killed as described under scenario A but remain in the blood component without any proliferation (growth pattern $\mathrm{C}$ in fig. 1). This observation is scientifically still not understood. Metabolic restrictions of typical environmental bacteria in the complex matrix of a platelet concentrate are the most likely explanation of that effect (e.g., missing of the so-called iron deficiency resistance, i.e., the bacteria are not able to utilise the strongly bound iron molecules in human plasma). Bacteria with such a growth pattern also account for false-negative results with early sampling.

The basic patterns of bacterial growth help to understand general factors which complicate the assessment of the effectiveness of pathogen reduction for bacteria. Measurements of 

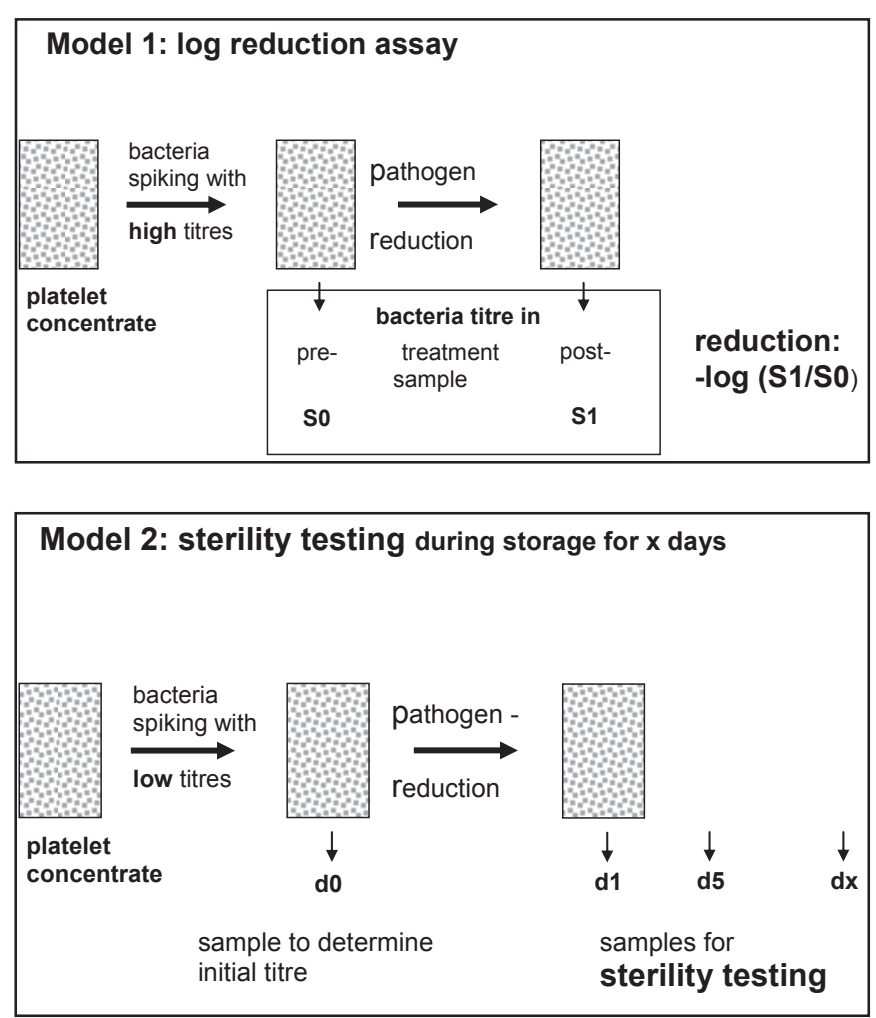

Fig. 2. Different study designs to assess the effectiveness of pathogen reduction procedures for bacteria.

the log reduction of the pathogen load have been established as a valid tool for the evaluation of the viral inactivation. The ability of bacteria to multiply during component storage introduces the need for additional experimental settings (fig. 2) for assessing the effectiveness of pathogen reduction procedures to prevent the transmission of bacterial infections.

An additional layer of complexity is introduced by the basic properties of bacteria groups (aerobic vs. anaerobic, Gram-positive vs. Gram-negative, etc.) including the ability of some bacteria to form spores. With these biological differences in mind, we want to address methodological requirements for a meaningful evaluation of pathogen reduction procedures with respect to bacteria.

\section{Measurement of Log Reduction of Bacteria in Blood Components}

Assays for determination of the reduction of the virus load are instrumental in assessing the virus elimination effectiveness. The virus reduction is usually measured as a function of the intensity of the treatment. This standard approach is often termed 'virus inactivation kinetics'. It has been utilised for bacteria inactivation experiments. The most common parameter to express the findings of these experiments is the ratio of the bacterial titres observed before treatment to the values immediately after treatment as reduction in log units (fig. 2).
Bacteria of a specific strain are seeded from a culture stock usually in the stationary phase into the platelet concentrate or other blood components. After adequate mixing, a sample is withdrawn to determine the initial bacterial titre. The pathogen reduction procedure is applied. Samples are drawn after pre-defined periods of illumination to determine the bacterial titres.

Serially diluted aliquots of the samples are finally evaluated in plate assays for enumeration of the colonies. The detection limit of these assays usually varies from 0.1 to 10 $\mathrm{CFU} / \mathrm{ml}$. The maximally achievable initial load of bacteria in the blood component and the detection limit of the plate assays define the upper limit for the log reductions to be observed. This upper limit can be as low as 4 log reduction steps. Procedures have thus been implemented to enhance the sensitivity of the bacterial titre determinations by an additional pre-incubation step with culture medium [35]. Biological variations of the bacterial growth in the components used for these inactivation experiments as well as the variability of the serial dilutions and plate assays contribute to the overall reproducibility of such investigations.

The first report of the potential of the final amotosalenUVA procedure following the initial publication of the proofof-principle [36] for the photochemical treatment of platelet concentrates to reduce pathogens [37] provides an example of these biological variations. The titres of Klebsiella pneumoniae observed for two platelet concentrates before treatment were comparable with $10^{3.8}$ and $10^{4.2} \mathrm{CFU} / \mathrm{ml}$. The lowest UVA doses of 0.5 in the presence of $150 \mu \mathrm{mol} / \mathrm{l}$ amotosalen resulted in titres of $10^{0}$ or $10^{1.7} \mathrm{CFU} / \mathrm{ml}$. Titres of $10^{-0.1}$ and $10^{1.0}$ $\mathrm{CFU} / \mathrm{ml}$ were observed after doubling the UVA exposure to $1.0 \mathrm{~J} / \mathrm{cm}^{2}$. These changes translated into $\log$ reductions of $2.3-3.9$ or 3.2-4.3. Illuminating the platelet concentrates with UVA light of an intensity of 2.0 and $3.0 \mathrm{~J} / \mathrm{cm}^{2}$, decreased the bacteria titres to values of $<10^{-0.1}$ (for both samples) and $10^{-0.1}$ or $10^{-2.5}$, respectively. The data clearly indicate that even at the therapeutic UVA dose of $3.0 \mathrm{~J} / \mathrm{cm}^{2}$ some variability in the titres is to be expected.

The variability of these findings for K. pneumoniae differs from the consistency of the results for the photochemical treatment of Staphylococcus epidermidis in the same study [37]. An UVA dose as low as $0.5 \mathrm{~J} / \mathrm{cm}^{2}$ did suffice for this bacteria strain to reduce the pre-treatment titre of $10^{4.1 \pm 0.6} \mathrm{CFU} / \mathrm{ml}$ to levels of $<10^{-0.1} \mathrm{CFU} / \mathrm{ml}$, i.e., below the limit of detection. The reproducible $\log$ reduction of at least 4.2 for all four UVA doses from 0.5 to $3 \mathrm{~J} / \mathrm{cm}^{2}$ together with additional findings [38] could indicate that Gram-positive bacteria are more susceptible to this photochemical treatment than Gram-negative bacteria. The authors suggested that the lipopolysaccharide surface of the outer membrane of Gram-negative bacteria can impair the penetration of amotosalen into these microbes. This finding of a relative higher resistance of a Gram-negative species to photochemical treatment has been confirmed and exploited in a more recent study [39]. The log 
reduction of $K$. pneumoniae by the amotosalen-UVA treatment was linearly correlated $\left(\mathrm{r}^{2}=0.845\right)$ with amotosalen photodegradation products quantified by HPLC and UV detection at $300 \mathrm{~nm}$. The higher resistance could be of clinical relevance as recipients treated with blood components contaminated with Gram-negative bacteria are at a higher risk of death compared to those receiving products containing Grampositive bacteria (odds ratio 7.5; $\mathrm{p}<0.01$ ) [20].

Table 1 summarizes the log reductions of a larger number of bacteria species observed for three different pathogen reduction procedures developed for platelet concentrates. In the study reported for UVA treatment $\left(320-400 \mathrm{~nm} ; 3 \mathrm{~J} / \mathrm{cm}^{2}\right)$ in the presence of amotosalen $(150 \mu \mathrm{mol} / \mathrm{l})$ the bacteria, with the exception of Bacillus cereus, were isolates from septic patients [38]. The platelet concentrates were collected by singledonor apheresis and the platelets were suspended in the final product in $35 \%$ plasma and $65 \%$ additive solution.

The second procedure [40-42] was also based on the treatment of single-donor apheresis platelets. Riboflavin was added to achieve a final concentration of $50 \mu \mathrm{mol} / \mathrm{l}$ in a platelet suspension with $90 \%$ residual plasma. This product was illuminated with UV light $(265-370 \mathrm{~nm} ; 6.2 \mathrm{~J} / \mathrm{ml})$ for about 9 min. The bacteria were preferentially samples from the American Type Culture Collection.

The third set of pathogen reduction experiments [43-44] was run with platelet concentrates prepared with the buffy coat procedure. Platelets suspended in additive solution and approximately $30 \%$ residual plasma were irradiated with UVC (254 nm wavelength) without addition of a photoactive agent and vigorously agitated. The bacteria investigated in these experiments were mainly bacterial standards of the Paul-Ehrlich Institute (Langen, Germany) thoroughly evaluated in platelet concentrates.

Comparable bacteria log reductions have been reported for pathogen reduction procedures developed for red blood cell concentrates [45-47].

This summary table already suggests that the value of $\log$ reduction assays may be somewhat limited for bacteria in contrast to viruses. The initial seeding number of bacteria does at least in some settings allow only for maximal reductions to be measured in the range of $4 \log$ steps. Log reduction activities observed from virus load reduction experiments can be related to the minimal virus dose required for an infective transmission. Log reduction findings from studies with bacteria and especially with rapidly multiplying bacteria, however, are much more difficult to extrapolate to clinical settings. Even if a single or very few bacteria survive the pathogen reduction procedure, the risk remains that these few microbes can grow to clinically significant numbers during the storage of the blood product following the pathogen reduction procedure [48-49]. This issue also illustrates the critical importance of the time windows to be specified for the application of the pathogen reduction procedure and the ensuing storage of the blood product. Sterility testing of the stored products after pathogen reduction of components loaded with comparably low but realistic numbers of bacteria (fig. 2) offers an alternative to the log reduction assays to address these issues.

\section{Sterility Testing of Blood Products Contaminated with a Low Bacteria Load}

The maximum of the efficacy for pathogen reduction to be observed in log reduction assays for bacteria is limited by the range between the bacterial titres achievable in the pre-treatment sample and the limit of detection for bacterial titres in the post-treatment sample. Thus experiments resulting in bacteria titres in the post-treatment samples below the detection limit have often been complemented by sterility testing of the blood component after treatment by drawing samples at the end of the storage period (fig. 2). Most log reduction experiments were repeated with a relatively small number of biological samples of usually of 4 or less. A meaningful analysis of sterility testing may require, however, observations of at least 6 independent biological samples due to the substantial variability associated with the detection of low numbers of bacteria.

In response to these limitations, experimental designs have been introduced as an alternative to the standard 'inactivation kinetics' approach. Their common aim is to check to which extent a pathogen reduction method is able to eliminate the risk that bacteria survive the treatment and multiply to meaningful levels during the storage period. Instead of seeding a very high number of bacteria, a relatively low number of bacteria is added to the blood component. After the pathogen reduction procedure has been completed, the blood component is stored under standard conditions until the shelf life of the product expires. Its sterility is then tested after this longest potential period for growth of bacteria surviving the pathogen reduction procedure.

The distribution of levels of bacteria to be expected in the blood from donors screened for whole blood or component donations is difficult to assess. In addition the specific composition of these preparations, e.g. the presence of leucoytes and the holding times [50], may further modify the initial load of bacteria in a blood component. Independent considerations of various authors $[14,34,48]$ suggest that numbers as low as 10-100 CFU/component may represent a realistic upper level of bacteria to be expected for endogenously (i.e. donor) contaminated blood preparations.

Experiments following such a design principle were first published for the amotosalen-UVA procedure [51]. Two platelet concentrates prepared from a pool of 5 buffy coats were pooled. The pooled preparation was then spiked with bacteria of 5 Gram-positive and 3 Gram-negative strains (titres: 4-3,900 CFU/ml). The pooled platelet concentrates were then split into two single concentrates. One platelet product was treated with amotosalen $(150 \mu \mathrm{mol} / \mathrm{l})$ and UVA 
Table 1. Log reduction of bacteria: comparison of 3 pathogen reduction procedures for platelet concentrates $[38,40,42,43]$

\begin{tabular}{|c|c|c|c|}
\hline & $\begin{array}{l}\text { Amotosalen and UVA } \\
\left(3 \mathrm{~J} / \mathrm{cm}^{2}\right) \\
(\mathrm{N}=4)\end{array}$ & $\begin{array}{l}\text { Riboflavin and UV } \\
(6.2 \mathrm{~J} / \mathrm{ml}) \\
(\mathrm{N}=6)\end{array}$ & $\begin{array}{l}\text { UVC } \\
\left(0.3 \mathrm{~J} / \mathrm{cm}^{2}\right) \\
(\mathrm{N}=6)\end{array}$ \\
\hline \multicolumn{4}{|l|}{ Gram-positive } \\
\hline \multicolumn{4}{|l|}{ Staphylococcus epidermidis } \\
\hline MDL collection ${ }^{\mathrm{a}}$ & $>6.6 \pm 0.1$ & & \\
\hline ATCC\# 12228 & & $\geq 4.2$ & \\
\hline PEI-B-06-04 & & & $4.8 \pm 0.5$ \\
\hline \multicolumn{4}{|l|}{ Staphylococcus aureus } \\
\hline MDL collection ${ }^{\mathrm{a}}$ & $6.6 \pm 0.1$ & & \\
\hline ATCC\# 25923 & & $3.6 \pm 0.35$ & \\
\hline ATCC\# 700787 & & $4.8 \pm 0.8$ & \\
\hline PEI-B-23-04 & & & $\geq 4.8$ \\
\hline \multicolumn{4}{|l|}{ Streptococcus pyogenes } \\
\hline MDL collectiona & $>6.8 \pm 0.1$ & & \\
\hline \multicolumn{4}{|l|}{ Listeria monocytogenes } \\
\hline MDL collectiona & $>6.3 \pm 0.1$ & & \\
\hline \multicolumn{4}{|l|}{ Corynebacterium minutissimum } \\
\hline MDL collectiona & $>6.3 \pm 0.1$ & & \\
\hline \multicolumn{4}{|l|}{ Bacillus cereus } \\
\hline Not reported: vegetative & $>5.5 \pm 0.2$ & & \\
\hline ATCC\# 7064 & & $1.9 \pm 0.3$ & \\
\hline Blood isolate & & $2.7 \pm 0.63$ & \\
\hline PEI-B-07-09 & & & $4.3 \pm 0.8$ \\
\hline \multicolumn{4}{|l|}{ Clostridium perfringens } \\
\hline PEI-B-25-03 & & & $\geq 4.7$ \\
\hline \multicolumn{4}{|l|}{ Propionibacterium acnes } \\
\hline ATCC\# 6919 & & & $4.5 \pm 1.1$ \\
\hline \multicolumn{4}{|l|}{ Gram-negative } \\
\hline \multicolumn{4}{|l|}{ Escherichia coli } \\
\hline MDL collection ${ }^{\mathrm{a}}$ & $>6.4 \pm 0.1$ & & \\
\hline ATCC\# 25922 & & $\geq 4.4$ & \\
\hline PEI-B-19-03 & & & $\geq 4.0$ \\
\hline \multicolumn{4}{|l|}{ Serratia marcescens } \\
\hline MDL collection ${ }^{\mathrm{a}}$ & $>6.7 \pm 0.1$ & & \\
\hline ATCC\# 43862 & & $4.0 \pm 0.5$ & $>5.0$ \\
\hline \multicolumn{4}{|l|}{ Klebsiella pneumoniae } \\
\hline MDL collection ${ }^{\mathrm{a}}$ & $>5.6 \pm 0.2$ & & \\
\hline PEI-B-08-07 & & & $4.8 \pm 0.3$ \\
\hline \multicolumn{4}{|l|}{ Enterobacter cloacae } \\
\hline MDL collection ${ }^{\mathrm{a}}$ & $5.9 \pm 0.1$ & & \\
\hline PEI-S-0075 & & & $\geq 4.3$ \\
\hline \multicolumn{4}{|l|}{ Pseudomonas aeruginosa } \\
\hline MDL collection ${ }^{\mathrm{a}}$ & $4.5 \pm 0.1$ & & \\
\hline ATCC\# 43088 & & $\geq 4.5$ & \\
\hline ATCC\# 27853 & & & $\geq 4.9$ \\
\hline \multicolumn{4}{|l|}{ Salmonella choleraesuis } \\
\hline MDL collectiona & $>6.2 \pm 0.1$ & & \\
\hline \multicolumn{4}{|l|}{ Yersinia enterocolitica } \\
\hline MDL collection ${ }^{\mathrm{a}}$ & $>5.9 \pm 0.2$ & & \\
\hline
\end{tabular}


Table 2. Frequency of BactT/ALERT-positive versus all cultures detected in samples drawn on days 1, 2 and 5 from bacterially contaminated platelet concentrates versus all platelet concentrates investigated as a function of the initial contamination level (day 0) [51]

\begin{tabular}{llll}
\hline Samples drawn on & \multicolumn{3}{l}{ Initial bacteria level } \\
\cline { 2 - 4 } & $1-10$ CFU/unit & $10-100$ CFU/unit & $100-1,000$ CFU/unit \\
\hline Day 1 & $1 / 7$ & $3 / 7$ & $6 / 7$ \\
Day 2 & $4 / 7$ & $6 / 6$ \\
Day 5 & $4 / 7$ & $5 / 7$ & $5 / 5$ \\
\hline
\end{tabular}

$\left(3 \mathrm{~J} / \mathrm{cm}^{2}\right)$, and the other portion served as the control. Samples (4 ml) for BacT/ALERT testing (up to $120 \mathrm{~h}$ ) were drawn on days 1, 5 and 7. Bacterial growth was detected in all the controls without photochemical treatment with the single exception of no detectable bacteria in the day-1 sample of the platelet concentrate inoculated with $80 \mathrm{CFU} / \mathrm{ml}$ of Staphylococcus epidermidis. The time from the start of the BacT/ALERT culture to a positive signal varied on day- 1 samples between $4.3 \mathrm{~h}$ and $100 \mathrm{~h}$, on day-5 samples between $3.0 \mathrm{~h}$ and $37 \mathrm{~h}$, and on day-7 samples between $2.7 \mathrm{~h}$ and $12.5 \mathrm{~h}$ for the controls. The samples taken from photochemically treated platelet concentrates were BacT/ALERT-negative with the exception of the concentrate inoculated with $12 \mathrm{CFU} / \mathrm{ml} \mathrm{B}$. cereus which yielded a positive signal in the BacT/ALERT system in all 3 follow-up samples: within $4.5 \mathrm{~h}$ (day-1 sample), $3.3 \mathrm{~h}$ (day-5 sample) and $3.2 \mathrm{~h}$ (day-7 sample) after starting the BacT/ ALERT testing. The other platelet concentrate also spiked with B. cereus $(180 \mathrm{CFU} / \mathrm{ml})$ was negative in all samples for the BacT/ALERT testing. The negative findings for the platelet concentrate contaminated with the lower count of $B$. cereus indicates that the photochemical treatment with amotosalen does not inactivate spores.

The reduction of bacteria by the amotosalen-UVA procedure has also been investigated for apheresis platelet concentrates in a modified experimental setting [52]. Double-dose platelet concentrates $\left(6 \times 10^{11}\right.$ platelets $)$ were prepared. Seven different bacteria (5 Gram-positives) were seeded in initial counts of 1-10, 10-100 and 100-1,000 CFU/concentrate. Each of these 21 double concentrates was split into 2 identical portions. One portion was photochemically treated after addition of amotosalen following an overnight incubation for bacterial growth (precise information about the duration of this incubation period were not reported). The other portion served as the control. Two samples (approximately $5 \mathrm{ml}$ each) were drawn from these preparations at $24 \pm 2 \mathrm{~h}$ (day 1), $48 \pm 2 \mathrm{~h}$ (day 2) and $120 \pm 2 \mathrm{~h}$ (day 5) after inoculation with the bacteria, and BacT/ALERT testing in aerobic and anaerobic bottles followed for $120 \mathrm{~h}$.

In the control platelet concentrates without the photochemical treatment at the lowest contamination level (1-10 CFU), only Staphyloccocus aureus showed positive BacT/ ALERT testing results from the day-1 sample. All other day-1 samples remained BacT/ALERT-negative. The results in samples collected on days 1, 2, and 5 from concentrates with 3 different contamination levels are summarised in table 2.
All samples drawn from the duplicate platelet concentrates treated with amotosalen and UVA following overnight storage were negative in the BacT/ALERT testing. The claim of consistent sterility of the products treated with the pathogen reduction procedure based on observations of only 3 platelet concentrates per bacteria needs to be confirmed for a higher number of inoculated platelet concentrates.

In a similar experimental setting, Goodrich et al. [34] compared the bacteria reduction of the riboflavin-UV procedure with the sensitivity of BacT/ALERT testing in platelet concentrates inoculated with low levels of bacteria (20-100 CFU/product). Double-dose apheresis platelet concentrates (>480 ml) were split into a $275 \mathrm{ml}$ portion for bacterial screening and a $185 \mathrm{ml}$ portion for the riboflavin-UV treatment. Both portions were then inoculated with the same dose of bacteria (target of 10-100 CFU/product). The 185-ml portion was then on hold for $2 \mathrm{~h}$ before the pathogen reduction procedure was performed. After storage of this portion for 7 days on a platelet incubator at $22^{\circ} \mathrm{C}$, samples ( $4 \mathrm{ml} / \mathrm{test}$ ) were taken for BacT/ALERT testing (for up to $168 \mathrm{~h}$ ) in an aerobic and an anaerobic bottle.

The untreated portion $(275 \mathrm{ml})$ was also stored and samples were drawn following the timing of the PASSPORT protocol [53]. Ten individual samples ( $8 \mathrm{ml}$ each) were drawn after storage for $24 \mathrm{~h}$. One additional sample was taken for aerobic and anaerobic BacT/ALERT testing from the residual platelet concentrate $(\approx 195 \mathrm{ml})$ after total storage for 7 days.

The authors evaluated in a total of 29 separate spiking experiments 20 different bacteria strains. Propionibacterium acnes, despite the highest inoculum of $600 \mathrm{CFU}$ per platelet concentrate, failed to multiply during the storage for 7 days. The samples taken from the product inoculated with this organism and stored for 7 days became BacT/ALERT-positive after $107 \pm 46 \mathrm{~h}$. All other bacteria multiplied in the platelet concentrates to high titres of at least $0.4 \times 10^{6} \mathrm{CFU} / \mathrm{ml}$ even for an initial inoculum of less than $10 \mathrm{CFU}$ per platelet preparation. It should be pointed out that the bacterial strains in contrast to the amotosalen-UVA study [38] summarised in table 2 - had been characterised prior to the study regarding their ability to multiply in platelet concentrates.

The authors of the study reported their findings as relative effectiveness, i.e., the \% portion of BacT/ALERT tests detecting bacteria or of the riboflavin-UV procedure leading to reduction of bacteria in day-7 samples below the detection 
limit of BacT/ALERT. In addition, they calculated an overall effectiveness (in \%) by multiplying the value observed for the relative effectiveness with the frequency of occurrence of the specific organism observed in the 3 haemovigilance studies: BACON, BacTHEM [54] and SHOT [55]. The database from these 3 studies included 60 reports. One third of all reports was associated with $S$. epidermidis. Escherichia coli, B. cereus, and $S$. aureus together contributed 21 additional cases. Thus, the four most frequent bacteria in these 3 studies accounted for at least two thirds of the reported cases. The authors also considered the initial bacterial contamination level for their direct comparison between the BacT/ALERT screening and the pathogen reduction procedure.

The overall effectiveness for bacterial screening (positive BacT/ALERT test within $24 \mathrm{~h}$ in the samples collected $24 \mathrm{~h}$ post preparation) was $66 \%$ for experiments with an initial contamination of less than $20 \mathrm{CFU}$ per platelet concentrate. The overall effectiveness even declined to only $60 \%$ if the bacterial screening data were limited to the findings in aerobic culture bottles only. It increased to $91 \%$ for platelet concentrates with an initial bacterial load of 20-100 CFU. The riboflavin-UV pathogen reduction procedure demonstrated a $98 \%$ and a $91 \%$ overall effectiveness for the platelet concentrates spiked with an inoculum of $<20 \mathrm{CFU}$ and 20-100 CFU per platelet concentrate, respectively. These data from spiking experiments suggest that bacterial screening is less efficient than the riboflavin-UV procedure when the initial load of bacteria is very low ( $<20 \mathrm{CFU}$ per platelet concentrate). The effectiveness of bacterial screening for early sampling (i.e., $24 \mathrm{~h}$ or less post preparation) observed in large clinical studies appears to vary from approximately 50 to $75 \%$. This similarity of the screening data in the clinical setting with the findings from spiking experiments could indicate that spiking experiments with very low inoculation titres (10-20 CFU) represent the clinically relevant contamination levels. The estimate of $98 \%$ effectiveness of the riboflavin-UV procedure remains to be confirmed by results following the introduction of the pathogen reduction procedure into the routine preparation of platelet concentrates.

The method utilized for direct comparison of pathogen reduction and bacterial screening has still to be validated also from a biological perspective. The absolute number of bacteria for the initial inoculum is identical for the bacterial screening portion of the platelet concentrate with a total volume of $275 \mathrm{ml}$ and the $185 \mathrm{ml}$ aliquot for the pathogen reduction arm of the study. This means that the bacteria number per $\mathrm{ml}$ is at least $30 \%$ lower for the screening arm than for the other arm.

The UVC method for pathogen reduction of platelet concentrates was also evaluated in the model of sterilisation of platelet concentrates contaminated with low levels of bacteria [43-44]. Platelet concentrates $\left(\approx 3.5 \times 10^{11}\right.$ platelets; $\approx 350 \mathrm{ml}$ ) were prepared by pooling of five buffy coats from whole blood donations. These preparations were spiked with bacteria to a final concentration of approximately $100 \mathrm{CFU} / \mathrm{ml}$
( $n=12 /$ bacteria species). An additional set of 12 platelet concentrates spiked with a target level of $10 \mathrm{CFU} / \mathrm{ml}$ was added if sterility was not observed for all 12 preparations of a bacteria species at the end of 6-day storage. The UVC irradiation followed the spiking, and the platelet concentrates were stored on a platelet incubator at $22 \pm 2{ }^{\circ} \mathrm{C}$ for $144 \mathrm{~h}$. BacT/ ALERT testing aerobic and anaerobic bottles was performed with $10 \mathrm{ml}$ samples for each bottle.

Eight different bacteria (4 Gram-positives) including the spore-forming $B$ cereus were investigated with this experimental design. All bacteria with 2 exceptions were strains provided and characterised in detail by the Paul-Ehrlich Institute.

UVC intensities of $0.25 \mathrm{~J} / \mathrm{cm}^{2}$, the intended standard dose of $0.3 \mathrm{~J} / \mathrm{cm}^{2}$, or $0.4 \mathrm{~J} / \mathrm{cm}^{2}$ were applied. All 96 platelet concentrates spiked with approximately $100 \mathrm{CFU} / \mathrm{ml}$ and treated with the standard dose of $0.3 \mathrm{~J} / \mathrm{cm}^{2} \mathrm{UVC}$ were sterile after 6 days of storage. The UVC dose of $0.25 \mathrm{~J} / \mathrm{cm}^{2}$ resulted in 4 non-sterile products at day 6 among the 96 platelet concentrates. Two preparations contaminated with $S$. aureus were positive in the BacT/ALERT test of their day-6 samples. Reducing the load to $10 \mathrm{CFU} / \mathrm{ml}$ resulted in sterility of all 12 preparations. The two other non-sterile platelet concentrates identified at day 6 of storage were spiked with $B$. cereus. This failure was also observed in $2 / 12$ preparations contaminated with $10 \mathrm{CFU} / \mathrm{ml}$. A failure to achieve sterility (in 1/12) was observed for this species even with the UVC dose of $0.4 \mathrm{~J} / \mathrm{cm}^{2}$. This indicates that spore formation [56] allows the bacteria to escape the pathogen reduction as also reported for the amotosalen-UVA procedure [51].

In summary, the observations in the models of sterility testing at the end of storage complement the observations from the elimination kinetic studies for bacteria. While these models may better represent the real life, the results do depend on various experimental details. Therefore, the findings from these different spiking studies need to be confirmed in the clinical setting. Besides factors including spiking dose, timing of both the pathogen reduction procedure and the sampling for bacterial detection as well as sample numbers and sample volume [57] for bacterial detection, the growth profile of the bacteria strains may be of high relevance for the validity of the specific model. Therefore a meaningful comparison of different procedures for pathogen reduction as well as the optimisation of these procedures should strongly benefit from bacteria standards.

\section{Need for Transfusion-Relevant Bacteria Standards}

Bacteria are usually maintained and propagated in optimised culture media. Bacteria from strains available from culture and tissue banks or as reference material do not necessarily grow reliably in blood components since they are selected following other purposes (e.g. for clinical microbiology, food 
or water microbiology etc.). During the past 10 years, a reference panel of transfusion-relevant bacterial strains has been systematically developed [58]. The members of this reference panel have been demonstrated to multiply reproducibly in platelet concentrates from more than 100 individual donors even when seeded with very low initial count (around 10 bacterial cells per platelet bag corresponding to $0.03 \mathrm{CFU} / \mathrm{ml}$ ). The results of the international validation study [58] were submitted to the WHO Expert Committee for Biological Standardization (ECBS). In October 2010, the panel has been established as WHO Repository Transfusion-Relevant Bacterial Reference Strains at the Paul Ehrlich Institute, Federal Institute for Vaccines and Biological Medicines, Langen, Germany. These bacterial standards are prepared and distributed as deep frozen suspensions by the Paul-Ehrlich Institute. They are shippable on dry ice and ready to use after thawing.

The international study was organized by the Working Party Transfusion Transmitted Infectious Disease (WP-TTID), Subgroup on Bacteria, of the International Society of Blood Transfusion (ISBT) for evaluation of these bacterial standards. 13 laboratories in 10 countries provided their results from the identification and enumeration and, additionally, from proliferation ability in platelet concentrates of blinded samples provided by the study coordination [58].
The bacterial strains were correctly identified in $98 \%$ of all 52 identifications (1 case reported as Staphylococcus delphini instead of the closely related S. epidermidis). S. pyogenes and E. coli grew in platelet concentrates in 11 out of 12 laboratories $(92.3 \%)$, K. pneumoniae and S. epidermidis replicated in all participating laboratories $(100 \%)$. The results of bacterial counts were very consistent between laboratories: the $95 \%$ confidence intervals were $1.19-1.32 \times 10^{7} \mathrm{CFU} / \mathrm{ml}$ for $S$. epidermidis, $0.58-$ $0.69 \times 10^{7} \mathrm{CFU} / \mathrm{ml}$ for $S$. pyogenes, $18.7-20.3 \times 10^{7} \mathrm{CFU} / \mathrm{ml}$ for K. pneumoniae, and 1.78-2.10 $\times 10^{7} \mathrm{CFU} / \mathrm{ml}$ for E. coli.

The study [58] was initiated as a pilot experiment (proof of principle) with the aim to demonstrate i) the quality, stability, and suitability of the bacterial strains for low-titre spiking of blood components, ii) the property of proliferation in platelet concentrates obtained from donors in different regions of the world, and iii) their suitability for and the logistics of worldwide shipping of deep frozen, blinded pathogenic bacteria. These aims were successfully fulfilled. Currently, a study is preparation in order to enlarge the panel to 10 or more suitable bacterial strains.

\section{Disclosure Statement}

The authors declared no conflicts of interest.

\section{References}

-1 Goldman M, Roy G, Frechette N, Decary F, Massicotte L, Delage G: Evaluation of donor skin disinfection methods. Transfusion 1997;37:309-312.

2 Hillyer CD, Josephson CD, Blajchman MA, Vosta JG, Epstein JS, Goodman JL: Bacterial contamination of blood components: risks, strategies, and regulation: Joint ASH and AABB educational session in transfusion medicine. Hematology Am Soc Hematol Educ Program 2003:575-589.

>3 Blajchman MA, Goldman M, Baeza F: Improving the bacteriological safety of platelet transfusions. Transfus Med Rev 2004;18:11-24.

4 Ramirez-Arcos S, Goldman M: Skin disinfection methods: prospective evaluation and postimplementation results. Transfusion 2010;50:59-64.

$\checkmark 5$ Benjamin RJ, Dy B, Warren R, Lischka M, Eder AF: Skin disinfection with a single-step $2 \%$ chlorhexidine swab is more effective than a two-step povidone-iodine method in preventing bacterial contamination of apheresis platelets. Transfusion 2011;51:531-538.

6 McDonald CP: Bacterial risk reduction by improved donor arm disinfection, diversion and bacterial screening. Transfus Med 2006;16:381-396.

7 de Korte D, Curvers J, de Kort WL, Hoekstra T, van der Poel CL, Beckers EA, Marcelis JH: Effects of skin disinfection method, deviation bag, and bacterial screening on clinical safety of platelet transfusions in the Netherlands. Transfusion 2006;46:476-485.
8 Satake M, Mitani T, Oikawa S, Nagumo H, Sugiura S, Tateyama H, Awakihara S, Mitsutomi Y, Muraoka M, Tadokoro K: Frequency of bacterial contamination of platelet concentrates before and after introduction of diversion method in Japan. Transfusion 2009;49:2152-2157.

9 McDonald CP, Rogers A, Cox M, Smith R, Roy A, Robbins S, Hartley S, Barbara JA, Rothenberg S, Stutzman L, Widders G: Evaluation of the $3 \mathrm{~d}$ BacT/ALERT automated culture system for the detection of microbial contamination of platelet concentrates. Transfus Med 2002;12:303-309.

10 Ribault S, Harper K, Grave L, Lafontaine C, Nannini P, Raimondo A, Faure IB: Rapid screening method for detection of bacteria in platelet concentrates. J Clin Microbiol 2004;42:1903-1908.

11 Castro E, Bueno JL, Barea L, Gonzalez R: Feasibility of implementing an automated culture system for bacteria screening in platelets in the blood bank routine. Transfus Med 2005;15:185-195.

12 McDonald CP, Pearce S, Wilkins K, Colvin J, Robbins S, Colley L, Taylor J, Barbara JA: Pall EBDS: An enhanced bacterial detection system for screening platelet concentrates. Transfus Med 2005;15:259-268

13 Schrezenmeier H, Walther-Wenke G, Müller TH, Weinauer F, Younis A, Holland-Letz T, Geis G, Asmus J, Bauerfeind U, Burkhart J, Deitenbeck R, Förstemann E, Gebauer W, Hochsmann B, Karakassopoulos A, Liebscher UM, Sanger W, Schmidt M, Schunter F, Sireis W, Seifried E: Bacterial contamination of platelet concentrates: results of a prospective multicenter study comparing pooled whole blood-derived platelets and apheresis platelets. Transfusion 2007;47:644-652.
14 Montag T: Strategies of bacteria screening in cellular blood components. Clin Chem Lab Med 2008;46:926-932.

15 Müller TH, Mohr H, Montag T: Methods for the detection of bacterial contamination in blood products. Clin Chem Lab Med 2008;46:933-946.

16 Murphy WG, Foley M, Doherty C, Tierney G, Kinsella A, Salami A, Cadden E, Coakley P: Screening platelet concentrates for bacterial contamination: low numbers of bacteria and slow growth in contaminated units mandate an alternative approach to product safety. Vox Sang 2008;95:13-19.

17 Pearce S, Rowe GP, Field SP: Screening of platelets for bacterial contamination at the Welsh blood service. Transfus Med 2011;21:25-32.

18 Stainsby D, Williamson L, Jones H, Cohen H: 6 years of shot reporting - its influence on UK blood safety. Transfus Apher Sci 2004:31:123-131.

19 Dodd RY: Bacterial contamination and transfusion safety: experience in the United States. Transfus Clin Biol 2003;10:6-9.

20 Kuehnert MJ, Roth VR, Haley NR, Gregory KR, Elder KV, Schreiber GB, Arduino MJ, Holt SC Carson LA, Banerjee SN, Jarvis WR: Transfusiontransmitted bacterial infection in the United States, 1998 through 2000. Transfusion 2001;41:1493-1499.

21 Walther-Wenke G, Doerner R, Montag T, Greiss $\mathrm{O}$, Hornei B, Knels R, Strobel J, Volkers P, Däubener W: Bacterial contamination of platelet concentrates prepared by different methods: results of standardized sterility testing in Germany. Vox Sang 2006;90:177-182. 
22 Brecher ME, Hay SN: Bacterial contamination of blood components. Clin Microbiol Rev 2005;18: 195-204.

-23 Allain JP, Bianco C, Blajchman MA, Brecher ME, Busch M, Leiby D, Lin L, Stramer S: Protecting the blood supply from emerging pathogens: the role of pathogen inactivation. Transfus Med Rev 2005;19: 110-126.

-24 Klein HG, Anderson D, Bernardi MJ, Cable R, Carey W, Hoch JS, Robitaille N, Sivilotti ML, Smaill F: Pathogen inactivation: making decisions about new technologies. Report of a consensus conference. Transfusion 2007;47:2338-2347.

25 Klein HG, Glynn SA, Ness PM, Blajchman MA: Research opportunities for pathogen reduction/ inactivation of blood components: summary of an NHLBI workshop. Transfusion 2009;49:1262-1268.

26 Webert KE, Cserti CM, Hannon J, Lin Y, Pavensk $\mathrm{K}$, Pendergrast JM, Blajchman MA: Proceedings of a consensus conference: pathogen inactivationmaking decisions about new technologies. Transfus Med Rev 2008;22:1-34

27 Pelletier JP, Transue S, Snyder EL: Pathogen inactivation techniques. Best Pract Res Clin Haemato 2006;19:205-242.

28 Seghatchian J, de Sousa G: Pathogen-reduction systems for blood components: the current position and future trends. Transfus Apher Sci 2006;35:189196.

29 Solheim BG: Pathogen reduction of blood components. Transfus Apher Sci 2008;39:75-82.

-30 Marschner S, Goodrich R: Pathogen reduction technology treatment of platelets, plasma and whole blood using riboflavin and UV light. Transfus Med Hemother 2011;38:8-18

31 Irsch J, Lin L: Pathogen inactivation of platelet and plasma blood components for transfusion using the INTERCEPT Blood System ${ }^{\mathrm{TM}}$. Transfus Med Hemother 2011;38:19-31.

32 Seltsam A, Müller TH: UVC irradiation for pathogen reduction of platelet concentrates and plasma Transfus Med Hemother 2011;38:43-54.

33 Henschler R, Seifried E, Mufti N: Development of the S-303 pathogen inactivation technology for red blood cell concentrates. Transfus Med Hemother 2011:33-42.

>34 Goodrich RP, Gilmour D, Hovenga N, Keil SD: A laboratory comparison of pathogen reduction technology treatment and culture of platelet products for addressing bacterial contamination concerns. Transfusion 2009;49:1205-1216.

- 35 Mohr H, Lambrecht B, Bayer A, Spengler HP, Nicol SB, Montag T, Müller TH: Sterility testing of platelet concentrates prepared from deliberately infected blood donations. Transfusion 2006;46:486491.

-36 Lin L, Londe H, Janda JM, Hanson CV, Corash L: Photochemical inactivation of pathogenic bacteria in human platelet concentrates. Blood 1994;83: 2698-2706.
37 Lin L, Cook DN, Wiesehahn GP, Alfonso R, Behrman B, Cimino GD, Corten L, Damonte PB, Dikeman R, Dupuis K, Fang YM, Hanson CV, Hearst JE, Lin CY, Londe HF, Metchette K, Nerio AT, Pu JT, Reames AA, Rheinschmidt M, Tessman J, Isaacs ST, Wollowitz S, Corash L: Photochemical inactivation of viruses and bacteria in platelet concentrates by use of a novel psoralen and long-wavelength ultraviolet light. Transfusion 1997;37:423-435.

38 Lin L, Dikeman R, Molini B, Lukehart SA, Lane R, Dupuis K, Metzel P, Corash L: Photochemical treatment of platelet concentrates with amotosalen and long-wavelength ultraviolet light inactivates a broad spectrum of pathogenic bacteria. Transfusion 2004;44:1496-1504.

39 Liu W, Cimino GD, Corash L, Lin L: The extent of amotosalen photodegradation during photochemical treatment of platelet components correlates with the level of pathogen inactivation. Transfusion 2011;51:52-61.

40 Ruane PH, Edrich R, Gampp D, Keil SD, Leonard RL, Goodrich RP: Photochemical inactivation of selected viruses and bacteria in platelet concentrates using riboflavin and light. Transfusion 2004; 44:877-885.

41 Goodrich RP, Edrich RA, Goodrich LL, Scott CA, Manica KJ, Hlavinka DJ, Hovenga NA, Hansen ET, Gampp D, Keil SD, Gilmour DI, Li J, Martin CB, Platz MS: Chapter 5: the antiviral and antibacterial properties of riboflavin and light: applications to blood safety and transfusion medicine; in Silva E, Edwards AM (eds): Flavins: Photochemistry and Photobiology, Vol. 6. London, The Royal Society of Chemistry, 2006, pp 83-113.

42 Goodrich RP, Edrich RA, Li J, Seghatchian J: The Mirasol PRT system for pathogen reduction of platelets and plasma: an overview of current status and future trends. Transfus Apher Sci 2006;35:5-17.

43 Mohr H, Gravemann U, Bayer A, Müller TH: Sterilization of platelet concentrates at production scale by irradiation with short-wave ultraviolet light. Transfusion 2009;49:1956-1963.

44 Mohr H, Steil L, Gravemann U, Thiele T, Hammer E, Greinacher A, Müller TH, Völker U: A novel approach to pathogen reduction in platelet concentrates using short-wave ultraviolet light. Transfusion 2009;49:2612-2624.

45 Zavizion B, Serebryanik D, Chapman J, Alford B, Purmal A: Inactivation of Gram-negative and Gram-positive bacteria in red cell concentrates using Inactine PEN110 chemistry. Vox Sang 2004; 87:143-149.

46 Wagner SJ, Skripchenko A, Cincotta L, Thompson-Montgomery D, Awatefe H: Use of a flexible thiopyrylium photosensitizer and competitive inhibitor for pathogen reduction of viruses and bacteria with retention of red cell storage properties. Transfusion 2005;45:752-760.

47 Skripchenko A, Wagner SJ, Thompson-Montgomery D, Awatefe $\mathrm{H}$ : Thiazole orange, a DNAbinding photosensitizer with flexible structure, can inactivate pathogens in red blood cell suspensions while maintaining red cell storage properties. Transfusion 2006;46:213-219.
8 Brecher ME, Holland PV, Pineda AA, Tegtmeier GE, Yomtovian R: Growth of bacteria in inoculated platelets: Implications for bacteria detection and the extension of platelet storage. Transfusion 2000;40:1308-1312.

49 Goodrich RP, Custer B, Keil S, Busch M: Defining 'adequate' pathogen reduction performance for transfused blood components. Transfusion 2010;50: 1827-1837.

50 Mohr H, Bayer A, Gravemann U, Müller TH: Elimination and multiplication of bacteria during preparation and storage of buffy coat-derived platelet concentrates. Transfusion 2006;46:949-955.

51 Knutson F, Alfonso R, Dupuis K, Mayaudon V, Lin L, Corash L, Hogman CF: Photochemical inactivation of bacteria and HIV in buffy-coat-derived platelet concentrates under conditions that preserve in vitro platelet function. Vox Sang 2000;78: 209-216.

52 Nussbaumer W, Allersdorfer D, Grabmer C, Rheinschmidt M, Lin L, Schönitzer D, Lass-Florl C: Prevention of transfusion of platelet components contaminated with low levels of bacteria: A comparison of bacteria culture and pathogen inactivation methods. Transfusion 2007;47:1125-1133.

53 Dumont LJ, Kleinman S, Murphy JR, Lippincott R, Schuyler R, Houghton J, Metzel P: Screening of single-donor apheresis platelets for bacterial contamination: the passport study results. Transfusion 2010;50:589-599.

54 Perez P, Salmi LR, Follea G, Schmit JL, de Barbeyrac B, Sudre P, Salamon R: Determinants of transfusion-associated bacterial contamination: results of the French BACTHEM Case-Control Study. Transfusion 2001;41:862-872.

55 Love EM, Soldan K: The Serious Hazards of Transfusion Steering Group. SHOT Annual Report 2000-2001. London, The Serious Hazards of Transfusion Group, 2002.

56 Störmer M, Vollmer T, Kleesiek K, Dreier J: Spore-forming organisms in platelet concentrates: a challenge in transfusion bacterial safety. Transfus Med 2008;18:371-376.

57 Wagner SJ, Eder AF: A model to predict the improvement of automated blood culture bacterial detection by doubling platelet sample volume. Transfusion 2007;47:430-433.

58 Störmer M, Arroyo A, Brachert J, Carrero H, Devine D, Epstein JS, Gabriel C, Gelber C, Goodrich R, Hanschmann KM, Heath DG, Jacobs MR, Keil S, de Korte D, Lambrecht B, Lee CK, Marcelis J, Marschner S, McDonald C, McGuane S, McKee M, Müller TH, Muthivhi T, Petterson A, Radziwon P, Ramirez-Arcos S, Reesink HW, Rojo J, Rood I, Schmidt M, Schneider CK, Seifried E, Sicker U, Wendel S, Wood EM, Yomtovian RH, Montag T: Establishment of the First International Repository for Transfusion Relevant Bacterial Reference Strains. Vox Sang 2011, accepted for publication. 